\title{
Helical Poly(5-alkyl-2,3-thiophene)s: controlled synthesis and structure characterization
}

\author{
Hong-Hai Zhang*, Chuanxu Ma, Peter V. Bonnesen, Jiahua Zhu, Bobby G. Sumpter, Jan-Michael Y. Carrillo, Panchao \\ Yin, Yangyang Wang, An-Ping Li, and Kunlun Hong*
}

Center for Nanophase Materials Sciences, Oak Ridge National laboratory, Oak Ridge, Tennessee, TN 37831

zhangh1@ornl.gov and hongkq@ornl.gov

\section{Supporting Information}

General: NMR spectra were recorded at $23{ }^{\circ} \mathrm{C}$ on a Varian VNMRS $500 \mathrm{MHz}$ NMR spectrometer, operating at $499.7 \mathrm{MHz}$ for proton, in $\mathrm{CDCl}_{3}$ unless otherwise noted. Chemical shifts were determined relative to residual $\mathrm{CHCl}_{3}(7.26 \mathrm{ppm})$ for proton, and to the $\mathrm{CDCl}_{3}$ "triplet" at $77.23 \mathrm{ppm}$ for carbon. NOESY spectra were acquired using a recycle delay of 1 second and a mixing time of 500 milliseconds, with $256 \mathrm{~T}_{1}$ increments and 32 scans per increment. For comparing P3HT and P5HT, samples with similar molecular weights (5500 and 6000 , respectively) were used. All yields reported refer to isolated yields unless otherwise indicated. $M \mathrm{n}$ and $M \mathrm{w} / M \mathrm{n}$ (PDI) value of polymers were measured with gel permeation chromatography (Waters Alliance 2695 separations module equipped with three polymer labs PLgel $5 \mu \mathrm{m}$ mixed C columns) using THF as eluent $(1 \mathrm{~mL} / \mathrm{min})$ at $40{ }^{\circ} \mathrm{C}$, which were calibrated with polystyrene standards. The experiment was performed with a home-made variabletemperature STM. All the images were acquired under the constant-current mode with a Pt-Ir tip at room temperature. Electronic absorption spectra were recorded using a quartz cell of $10 \mathrm{~mm}$ path length on a Cary 5000 UV-vis-NIR spectrophotometer. MALDI-TOF mass spectra were recorded on a Bruker Reflex III in the reflection mode with a laser $(\lambda=337 \mathrm{~nm})$ using $1,1,4,4-$ tetraphenyl-1,3-butadiene as a matrix. All the solvents were degassed for $2 \mathrm{~h}$ before use. All the reagents were purchased from commercial sources and used as received. 2-bromo-5alkylthiophene (2) was prepared according to the reported procedure. ${ }^{1} \mathrm{P} 3 \mathrm{HT}$ was prepared in the way similar to the literature. ${ }^{2}$

Synthetic route to monomer 3

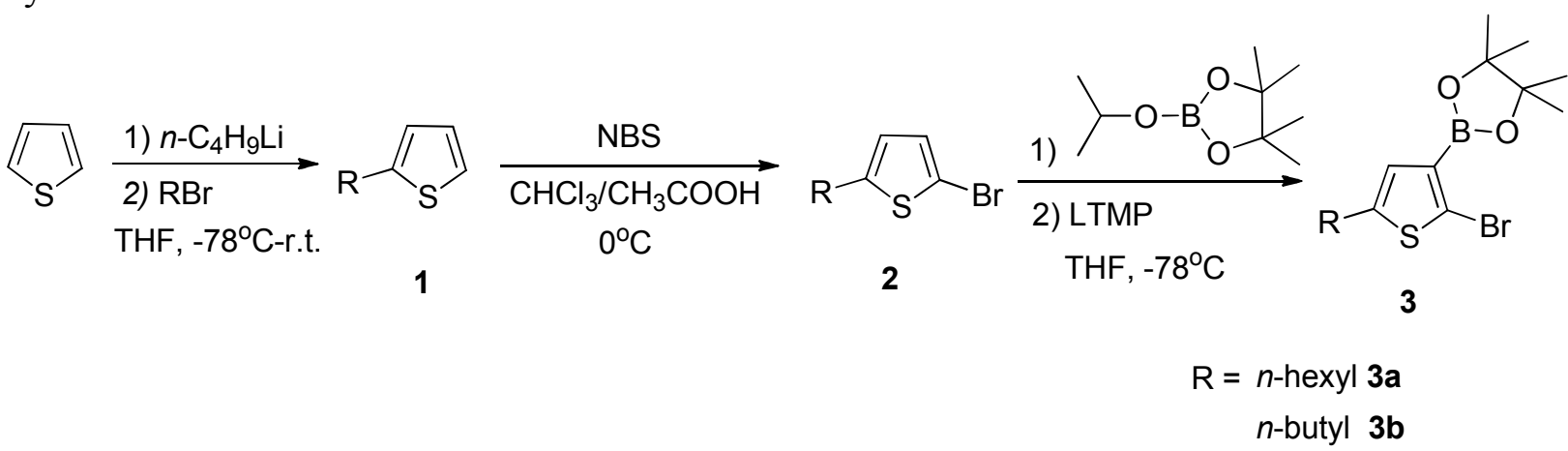

In situ quenching procedure for preparation of monomer 3 from compound 2: The solution of Compound 2 (20 mmol, 1 equiv.) and 2-isopropoxy-4,4,5,5-tetramethyl-1,3,2-dioxaborolane 
(30 mmol, 1.5 equiv.) in THF $(20 \mathrm{~mL})$ was added dropwise into the solution of lithium tetramethylpiperidide (LTMP, $22 \mathrm{mmol}, 1.1$ equiv.) in THF $(100 \mathrm{~mL})$ in a $250-\mathrm{mL}$ three-neck round bottom flask under nitrogen at $-78{ }^{\circ} \mathrm{C}$. The reaction was performed until the GC/MS showed the reaction was completed. The reaction was quenched with saturated $\mathrm{NH}_{4} \mathrm{Cl}$ solution. The product was extracted with dichloromethane $(3 \times 15 \mathrm{~mL})$. The combined organic layer was washed with brine and dried over $\mathrm{Na}_{2} \mathrm{SO}_{4}$. After removal of solvents under vacuum, the crude product was purified via column chromatography (silica gel, hexane: $\mathrm{CH}_{2} \mathrm{Cl}_{2}=4: 1$ ).

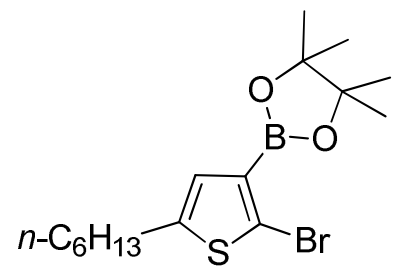

3a: Yield: $60 \%$ brown oil. ${ }^{1} \mathrm{H}$ NMR: $\delta 6.81(\mathrm{~s}, 1 \mathrm{H}), 2.72(\mathrm{t}, J=8.0 \mathrm{~Hz}, 2$ $\mathrm{H}), 1.57 \sim 1.65(\mathrm{~m}, 2 \mathrm{H}), 1.34(\mathrm{~s}, 12 \mathrm{H}), 1.28 \sim 1.31(\mathrm{~m}, 6 \mathrm{H}), 0.89(\mathrm{t}, J=7.0 \mathrm{~Hz}, 3 \mathrm{H}) ;{ }^{13} \mathrm{C}$ NMR: $\delta 146.8,129.8,119.4,83.7,31.3,29.9,28.6,24.8,22.5,14.0$.

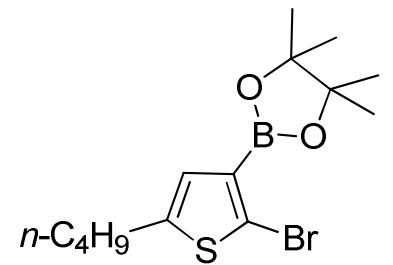

$\mathrm{H}), 1.60 \sim 1.63(\mathrm{~m}, 2 \mathrm{H}), 1.32 \sim 1.38(\mathrm{~m}, 14 \mathrm{H}), 0.92(\mathrm{t}, J=7.5 \mathrm{~Hz}, 3 \mathrm{H}) ;{ }^{13} \mathrm{C}$ NMR: $\delta 146.7$, $129.9,119.4,83.7,33.4,29.6,24.8,22.1,13.7$.

\section{Determination of the structure of monomer 3a:}

GC-MS showed the molecular weight of monomer 3a is $372.7 \mathrm{~g} / \mathrm{mol}$ and the purity of it is $>98 \%$. As has been reported in the literature ${ }^{1}$, when LDA or LTMP react with compound $2 \mathbf{a}$, the proton abstracted/lithiated is always the one adjacent to bromide. The gCOSY spectrum of monomer 3a (Figure s1) also showed the proton in thiophene ring does display weak two-bond coupling to the protons of the alpha- methylene group (attached to the thiophene ring) of the hexyl side chain. We also prepared the 3-bromo-5-hexylthiophen-2-ylboronic acid pinacol ester (s1) following the reported procedure and compared the proton and carbon NMR spectrum of monomer 3a and s1. ${ }^{1}$ The difference in carbon and proton NMR spectrum indicated that the compound (monomer 3a) obtained from the in situ quenching procedure has a different structure than compound s1 (Figure s2). To further confirm the structure of monomer 3a, we followed the reported procedure to convert the bromide in monomer 3a to proton. The result product showed the same ${ }^{1} \mathrm{H}-\mathrm{NMR}$ spectrum with 5-hexylthiophen-3-ylboronic acid pinacol ester prepared by Mullen's procedure. ${ }^{3}$ This result indicated that the boronic acid pinacol ester group should be at the 3 position of the thiophene ring. In conclusion, the monomer 1a prepared by in situ quenching procedure should be 2-bromo-5-hexylthiophen-3-ylboronic acid pinacol ester. 


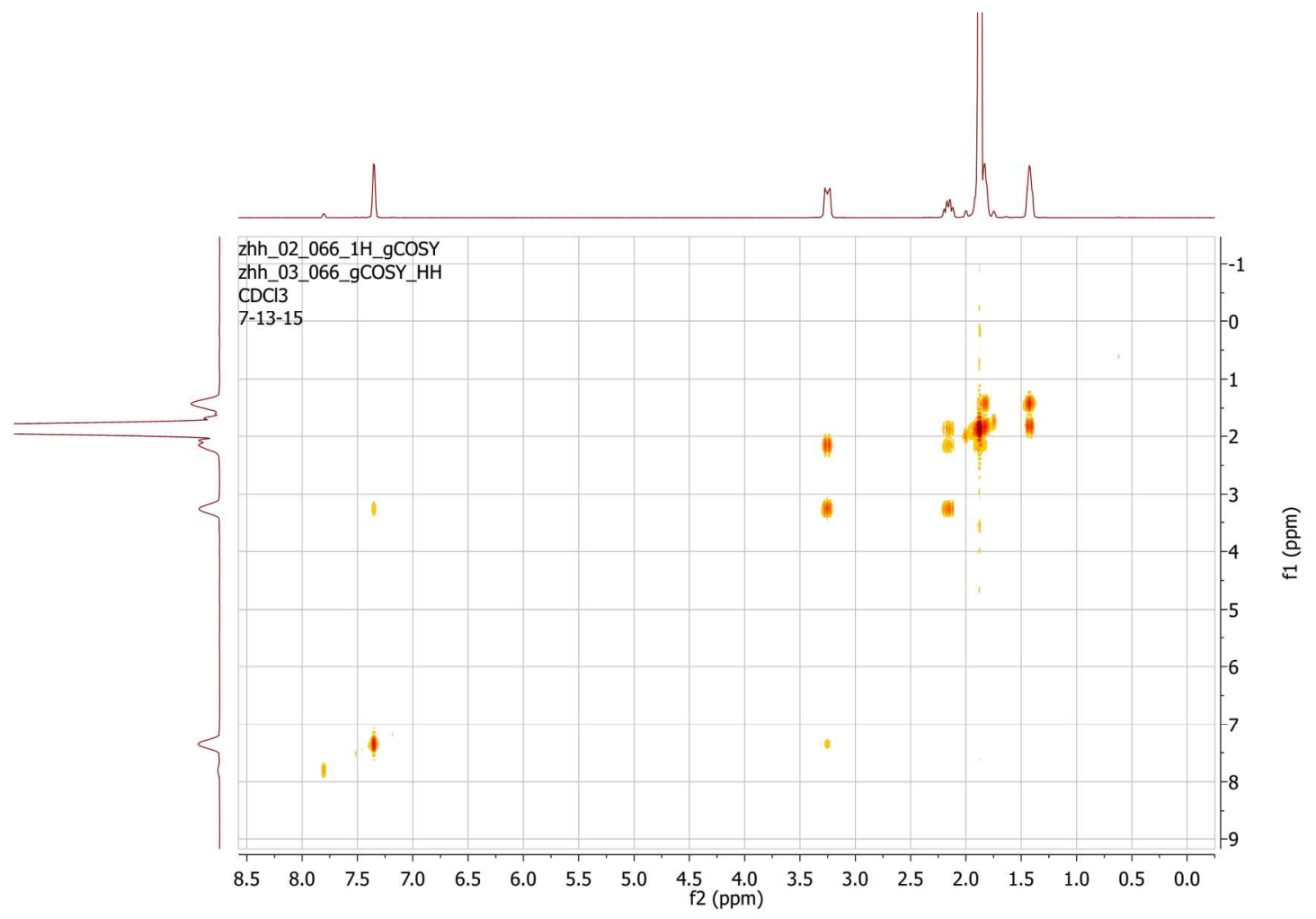

Figure $\mathrm{S} 1$ : gCOSY spectrum of monomer $3 \mathrm{a}$ in $\mathrm{CDCl}_{3}$

Synthetic route to compound $\mathbf{s} 3$ followed by reported procedure ${ }^{1}$ :

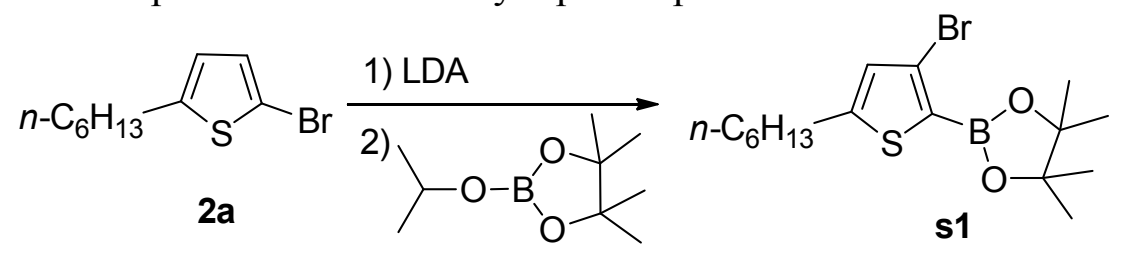

$\mathrm{THF},-78^{\circ} \mathrm{C}$

Preparation of compound $\mathbf{s} 1$ from compound 2a: The solution of lithium diisopropylamine (LDA, $22 \mathrm{mmol}, 1.1$ equiv) in THF $(20 \mathrm{~mL})$ was added dropwise into the solution of compound 2a (20 mmol, 1 equiv) in a $250-\mathrm{mL}$ three-neck round bottom flask under nitrogen at $-78{ }^{\circ} \mathrm{C}$. The mixture was stirred for one hour at $-78{ }^{\circ} \mathrm{C}$. Then 2 -isopropoxy-4,4,5,5-tetramethyl-1,3,2dioxaborolane ( $30 \mathrm{mmol}, 1.5$ equiv) in THF $(20 \mathrm{~mL})$ was injected into the mixture at $-78{ }^{\circ} \mathrm{C}$ and the mixture was allowed to slowly warm to room temperature. The reaction was performed until the GC/MS showed the reaction was completed. The reaction was quenched with saturated $\mathrm{NH}_{4} \mathrm{Cl}$ solution. The product was extracted with dichloromethane $(3 \times 15 \mathrm{~mL})$. The combined organic layer was washed with brine and dried over $\mathrm{Na}_{2} \mathrm{SO}_{4}$. After removal of solvents under vacuum, the crude product was purified via column chromatography (silica gel, hexane: $\mathrm{CH}_{2} \mathrm{Cl}_{2}=$ $4: 1)$. 


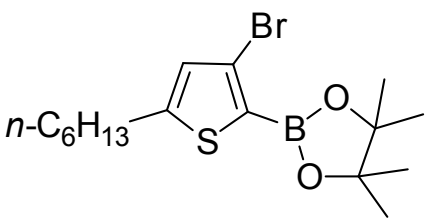

s1: Yield: $68 \%$ brown oil. ${ }^{1} \mathrm{H}$ NMR: $\delta 6.80(\mathrm{~s}, 1 \mathrm{H}), 2.78(\mathrm{t}, J=8.0 \mathrm{~Hz}, 2 \mathrm{H}), 1.63 \sim 1.66(\mathrm{~m}, 2$ $\mathrm{H}), 1.34(\mathrm{~s}, 12 \mathrm{H}), 1.27 \sim 1.29(\mathrm{~m}, 6 \mathrm{H}), 0.88(\mathrm{t}, J=7.0 \mathrm{~Hz}, 3 \mathrm{H}) ;{ }^{13} \mathrm{C}$ NMR: $\delta$ 153.6, 130.1, $119.2,84.3,31.7,31.3,30.3,28.8,24.9,22.7,14.2$.
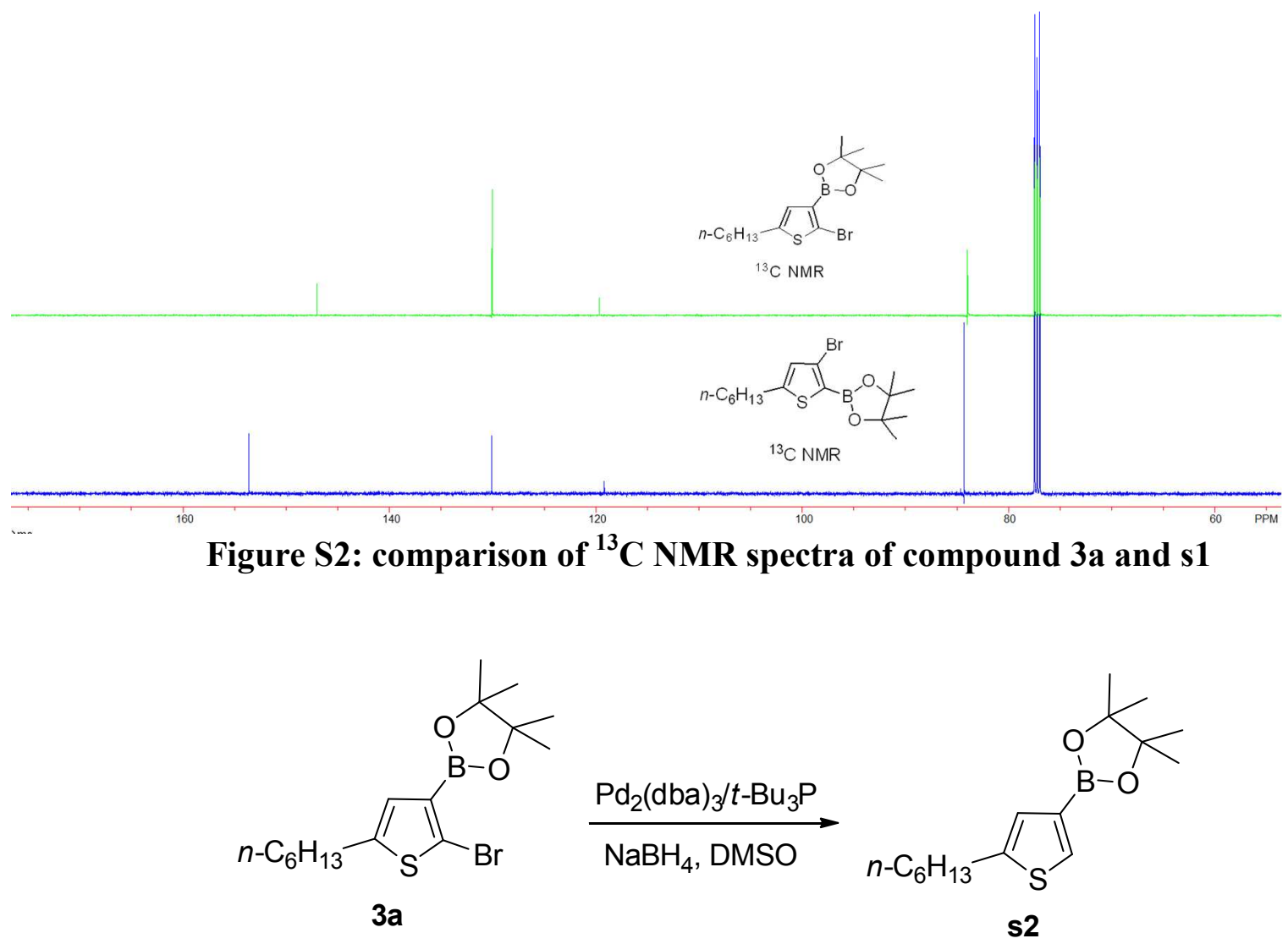

Procedure for reduction of compound 3a to s2: In an argon glovebox, to $8 \mathrm{~mL}$ vial containing $\mathrm{Pd}_{2}(\mathrm{dba})_{3}(18.3 \mathrm{mg}, 0.02 \mathrm{mmol}), t-\mathrm{Bu}_{3} \mathrm{P}$ (12 $\left.\mathrm{mg}, 0.06 \mathrm{mmol}\right), \mathrm{NaBH}_{4}(80 \mathrm{mg}, 2 \mathrm{mmol})$, and compound 3a $(1 \mathrm{mmol})$ was added DMSO $(2 \mathrm{~mL})$. The reaction was performed at $60{ }^{\circ} \mathrm{C}$ until the $\mathrm{GC} / \mathrm{MS}$ showed the reaction was completed. The reaction was quenched with saturated $\mathrm{NH}_{4} \mathrm{Cl}$ solution. The product was extracted with dichloromethane $(3 \times 15 \mathrm{~mL})$. The combined organic layer was washed with brine and dried over $\mathrm{Na}_{2} \mathrm{SO}_{4}$. After removal of solvents under vacuum, the crude product was purified via column chromatography (silica gel, hexane: $\mathrm{CH}_{2} \mathrm{Cl}_{2}=4: 1$ ).

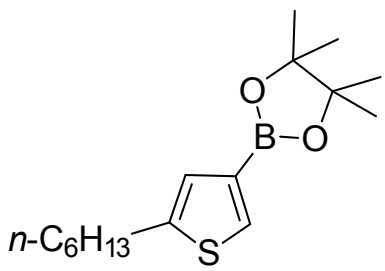


s2: Yield: $85 \%$ brown oil. ${ }^{1} \mathrm{H}$ NMR: $\delta 7.69(\mathrm{~s}, 1 \mathrm{H}), 7.05(\mathrm{~s}, 1 \mathrm{H}), 2.80(\mathrm{t}, J=8.0 \mathrm{~Hz}, 2 \mathrm{H}), 1.63 \sim$ $1.66(\mathrm{~m}, 2 \mathrm{H}), 1.28 \sim 1.34(\mathrm{~m}, 18 \mathrm{H}), 0.88(\mathrm{t}, J=7.0 \mathrm{~Hz}, 3 \mathrm{H}) ;{ }^{13} \mathrm{C}$ NMR: $\delta 144.2,132.5,126.8$, $81.6,29.7,29.6,27.7,26.8,22.8,20.6,12.1$.

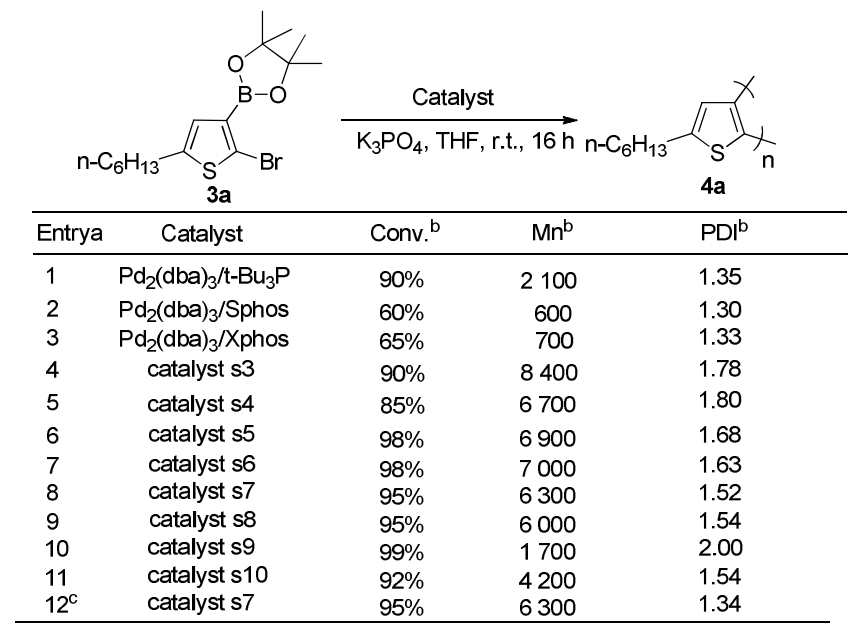

a. Polymerization condition: monomer $(0.1 \mathrm{mmol})$, Pd catalyst $(4 \mathrm{~mol} \%), \mathrm{K}_{3} \mathrm{PO}_{4}$ (10 equiv $2 \mathrm{M}$ solution in $\left.\mathrm{H}_{2} \mathrm{O}\right)$, THF $(6 \mathrm{~mL})$, r.t. $16 \mathrm{~h}$. b. GPC analysis (polystyrene as standard, THF, 40 oC). c. Condition: monomer $(0.1 \mathrm{mmol})$, catalyst $6(4 \mathrm{~mol} \%)$, $\mathrm{K}_{3} \mathrm{PO}_{4}$ (10 equiv. solid), $\mathrm{H}_{2} \mathrm{O}(0.3 \mathrm{~mL})$, THF $(6 \mathrm{~mL})$, r.t. $16 \mathrm{~h}$.
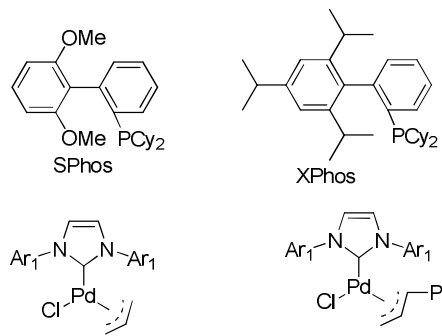

catalyst s3

$\operatorname{Ar}_{1}-{ }^{-N} Y^{N}-\operatorname{Ar}_{1}$

$\mathrm{Cl}-\mathrm{Pd}$

Cl ${ }_{\mathrm{Pd}-\mathrm{Cl}} \mathrm{Cl}$

$\mathrm{Ar}_{1}-\mathrm{N}_{\mathrm{N}}-\mathrm{Ar}_{1}$

catalyst $\mathrm{s} 6$

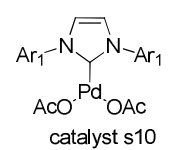

XPhos
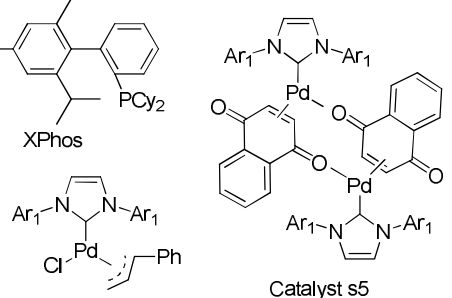

catalyst 54

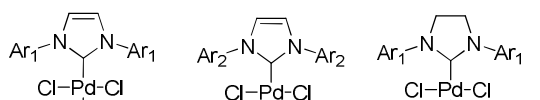

$\mathrm{N}^{\mathrm{N}}$

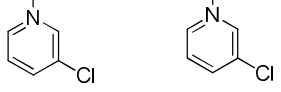

catalyst s7 catalyst s8 catalyst s9

Table S1. Pd catalyst screening for Suzuki cross-coupling polymerization of 2-bromo-5hexylthiophen-3-ylboronic acid pinacol ester

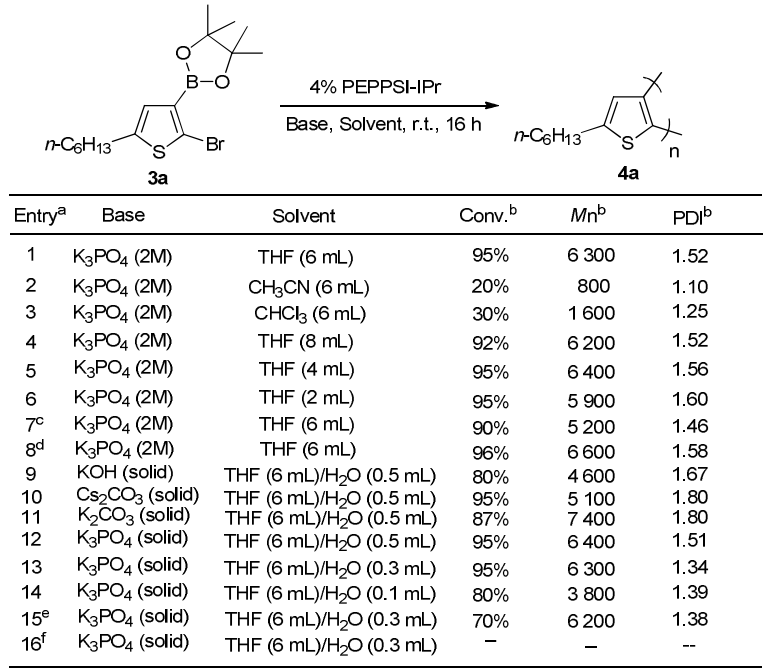

a. Polymerization condition: monomer $(0.1 \mathrm{mmol})$, PEPPSI-IPr $(4 \mathrm{~mol} \%), \mathrm{K}_{3} \mathrm{PO}_{4}(2 \mathrm{M}$ solution in $\mathrm{H}_{2} \mathrm{O}, 0.5 \mathrm{~mL}, 10$ equiv.), solvent, r.t. $16 \mathrm{~h}$. b.GPC analysis (polystyrene as standard, $\left.\mathrm{THF}, 40^{\circ} \mathrm{C}\right)$. c. $0.2 \mathrm{~mL}$ of $\mathrm{K}_{3} \mathrm{PO}_{4}$ solution $\left(2 \mathrm{M} \mathrm{in}_{2} \mathrm{O}\right.$ ) was used. d. $1.0 \mathrm{~mL}$ of

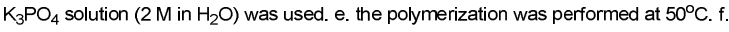

the polymerization was performed at $0^{\circ} \mathrm{C}$

Table S2: Screening conditions for PEPPSI-IPr catalyzed polymerization of 2-bromo-5hexylthiophen-3-ylboronic acid pinacol ester 
General Procedure for polymerization of 2-bromo-5-hexylthiophen-3-ylboronic acid pinacol ester: In an argon glovebox, to $20 \mathrm{~mL}$ vial containing PEPPSI-IPr (26 mg, $0.04 \mathrm{mmol})$, 2-bromo-5-hexylthiophen-3-ylboronic acid pinacol ester $(1.0 \mathrm{mmol})$ and $\mathrm{K}_{3} \mathrm{PO}_{4}(2.12 \mathrm{~g}, 10$ mmol) was added THF $(6 \mathrm{~mL})$. Then water $(0.3 \mathrm{~mL})$ was injected into the mixture. The reaction was performed at room temperature for 16 hours. The reaction was quenched with $2 \mathrm{M} \mathrm{HCl}$ solution. The product was extracted with dichloromethane $(3 \times 40 \mathrm{~mL})$. The combined organic layer was washed with brine and dried over $\mathrm{Na}_{2} \mathrm{SO}_{4}$. After removal of solvents under vacuum, the residue was dissolved in minimum amount of THF and added dropwise to methanol $(50 \mathrm{~mL})$. The solid was collected by filtration and dried under vacuum.

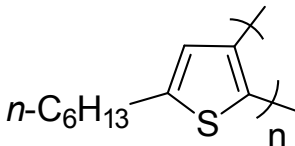

4a: yellow solid. Yield: $70 \%, M n=6200$, PDI $=1.35 .{ }^{1} \mathrm{H}$ NMR: $\delta 6.26(\mathrm{~s}, 1$ H), $2.55(\mathrm{t}, J=5.5 \mathrm{~Hz}, 2 \mathrm{H}), 1.49 \sim 1.53(\mathrm{~m}, 2 \mathrm{H}), 1.26 \sim 1.28(\mathrm{~m}, 6 \mathrm{H}), 0.87(\mathrm{t}, J=7.0 \mathrm{~Hz}, 3 \mathrm{H})$; ${ }^{13} \mathrm{C}$ NMR: $\delta$ 143.1, 133.1, 130.7, 126.8, 31.7, 31.5, 30.0, 28.9, 22.6, 14.1.

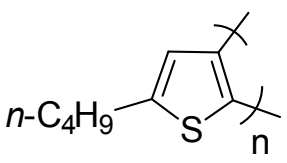

4b: yellow solid. Yield: $69 \%, M \mathrm{n}=3500$, PDI $=1.28$; Yield: $65 \%, M \mathrm{n}=6$ 700, PDI = 1.53. ${ }^{1} \mathrm{H}$ NMR: $\delta 6.27(\mathrm{~s}, 1 \mathrm{H}), 2.56(\mathrm{t}, J=7.5 \mathrm{~Hz}, 2 \mathrm{H}), 1.46 \sim 1.54(\mathrm{~m}, 2 \mathrm{H}), 1.25 \sim$ $1.32(\mathrm{~m}, 2 \mathrm{H}), 0.86(\mathrm{t}, J=7.5 \mathrm{~Hz}, 3 \mathrm{H}) ;{ }^{13} \mathrm{C} \mathrm{NMR}: \delta 143.1,133.2,130.8,126.9,33.6,29.7,22.1$, 13.9 .

The polymerization of 2-bromo-5-hexylthiophen-3-ylboronic acid pinacol ester with different amounts of PEPPSI-IPr $(16,12,8,4,2$ and $1 \mathrm{~mol} \%)$ was performed in a manner similar to the general procedure described in the [General Procedure for polymerization of 2-bromo-5hexylthiophen-3-ylboronic acid pinacol ester] except different initiator loadings. The polymer yields were $63 \%, 67 \%, 68 \%, 70 \%, 65 \%$ and $65 \%$ respectively and $\mathrm{Mn}$ (PDI) were found to be 4000 (1.31), 4800 (1.29), 5400 (1.34), 6200 (1.34), 8000 (1.57) and 9100 (1.64), respectively.
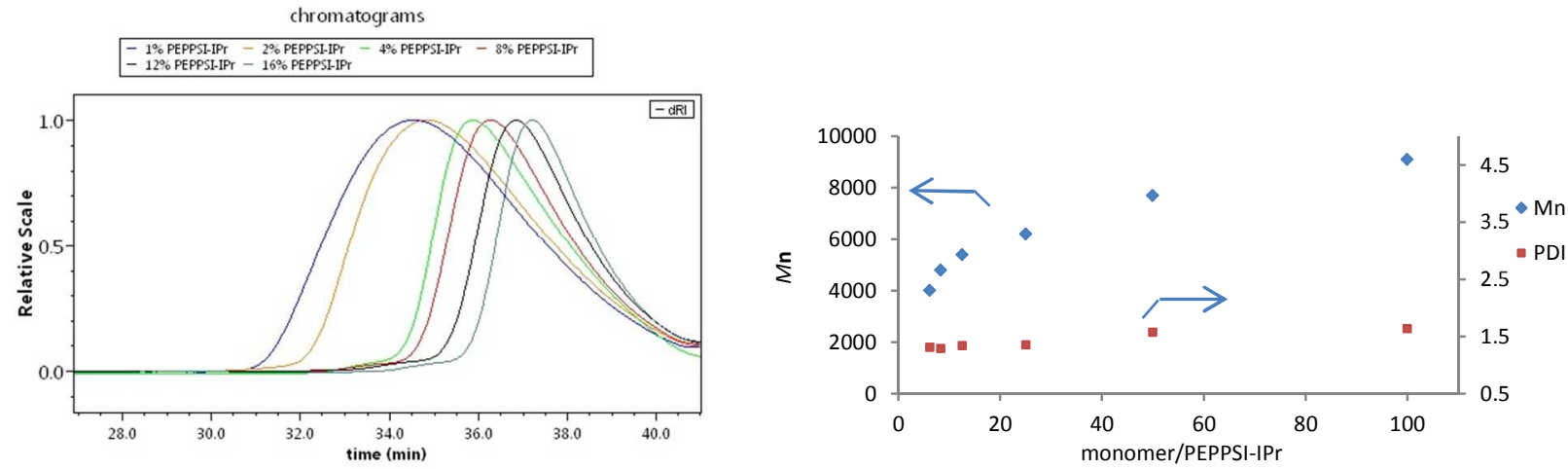

Figure S3: GPC profile and polymerization of 2-bromo-5-hexylthiophen-3-ylboronic acid pinacol ester with different catalyst loading 
Molecular weight-conversion relationship study for PEPPSI-IPr catalyzed polymerization of 2bromo-5-hexylthiophen-3-ylboronic acid pinacol ester: In an argon glovebox, to $20 \mathrm{~mL}$ vial containing PEPPSI-IPr $(5.2 \mathrm{mg}, 0.008 \mathrm{mmol}), 2$-bromo-5-hexylthiophen-3-ylboronic acid pinacol ester $(75 \mathrm{mg}, 0.2 \mathrm{mmol})$ and $\mathrm{K}_{3} \mathrm{PO}_{4}(424 \mathrm{mg}, 2.0 \mathrm{mmol})$ was added THF $(12 \mathrm{~mL})$. Then water $(0.6 \mathrm{~mL})$ was injected into the mixture. The reaction was performed at room temperature. A small aliquot $(0.3 \mathrm{~mL})$ of the organic phase of the reaction mixture was sampled at $45,60,75$, $90,105,120,150,180 \mathrm{~min}$. Each aliquot was quenched with $6 \mathrm{~N} \mathrm{HCl}$ solution and extracted with $\mathrm{CH}_{2} \mathrm{Cl}_{2}$. The separated organic layer was evaporated under reduced pressure to get a residue. Half of the residue was dissolved in $\mathrm{CDCl}_{3}$ to determine the conversion of monomer by ${ }^{1} \mathrm{H}$ NMR (conversions of $25 \%, 36 \%, 45 \%, 54 \%, 65 \%, 78 \%, 90 \%$ and $95 \%$ were observed for $45,60,75$, $90,105,120,150$ and $180 \mathrm{~min}$, respectively). The other half of the residue was dissolved in THF and the solution was filtered. The filtrate was analyzed by GPC to determine the $M \mathrm{n}$ and $M \mathrm{w} / M \mathrm{n}$ values of the polymers. The $M \mathrm{n}(M \mathrm{w} / M \mathrm{n})$ values of each polymer for $45,60,75,90,105,120$, 150 and $180 \mathrm{~min}$ were 3400 (1.16), 3600 (1.24), 4000 (1.26), 4500 (1.28), 5000 (1.32), 5100 (1.34), 5500(1.37) and $6000(1.37)$ respectively.
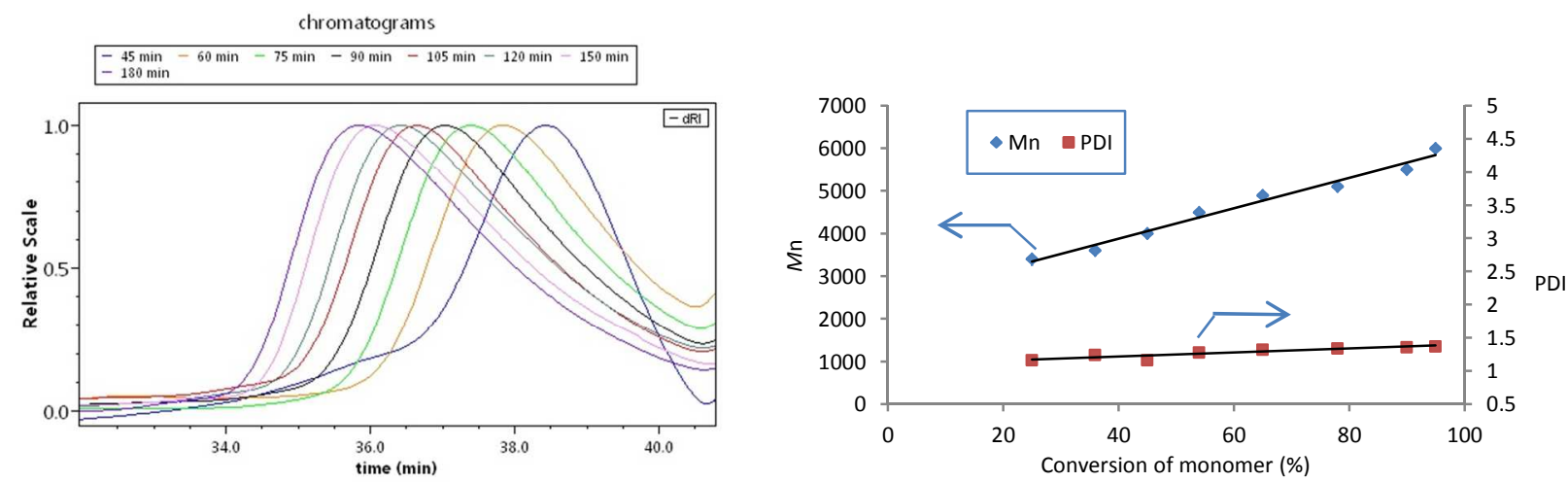

Figure S4: GPC profile and molecular weight-conversion relationship for PEPPSI-IPr catalyzed polymerization of 2-bromo-5-hexylthiophen-3-ylboronic acid pinacol ester

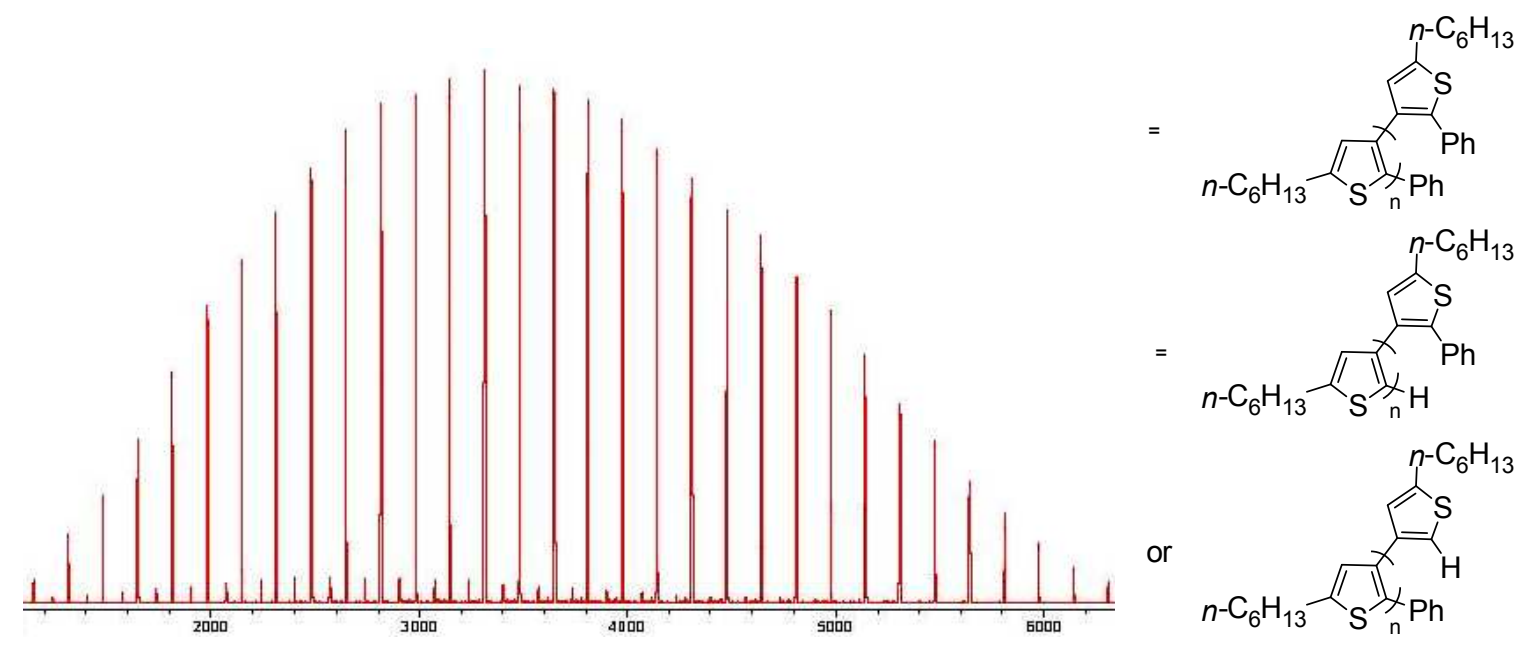

Figure S5: MALDI-TOF spectrum of PEPPSI-IPr (16\%) catalyzed polymerization of 2bromo-5-hexylthiophen-3-ylboronic acid pinacol ester quenching with phenylboronic acid 
STM study: The experiment was performed with a home-made variable-temperature STM. All the images were acquired under the constant-current mode with a Pt-Ir tip at room temperature. The sample of P5BT suitable for STM analysis was prepared as follows: eight drops of P5BT in THF $(0.02 \mathrm{mg} / \mathrm{mL})$ were deposited on freshly dried HOPG under nitrogen flow for five minutes before being transferred to the ultrahigh vacuum.

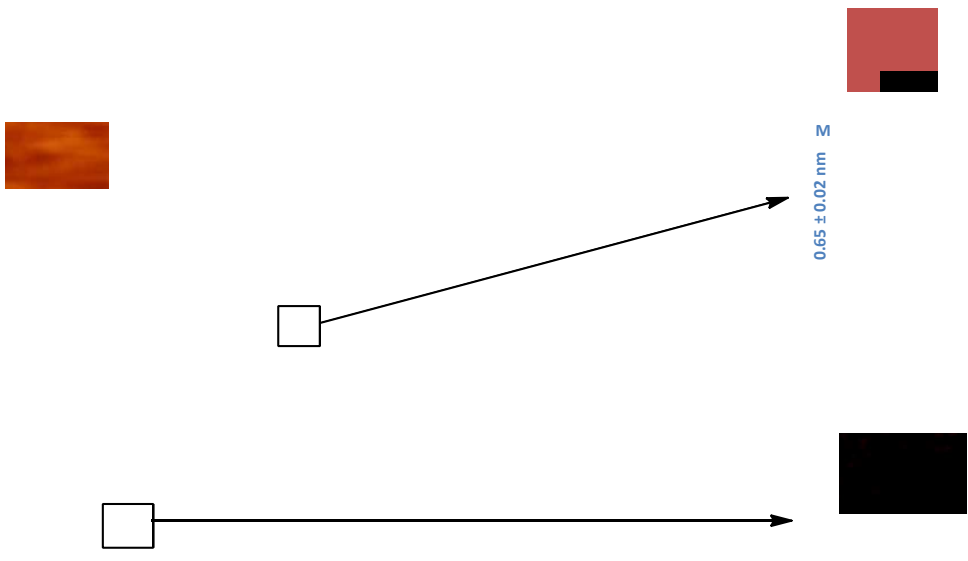

Figure S6: STM current image of P5BT on HOPG.
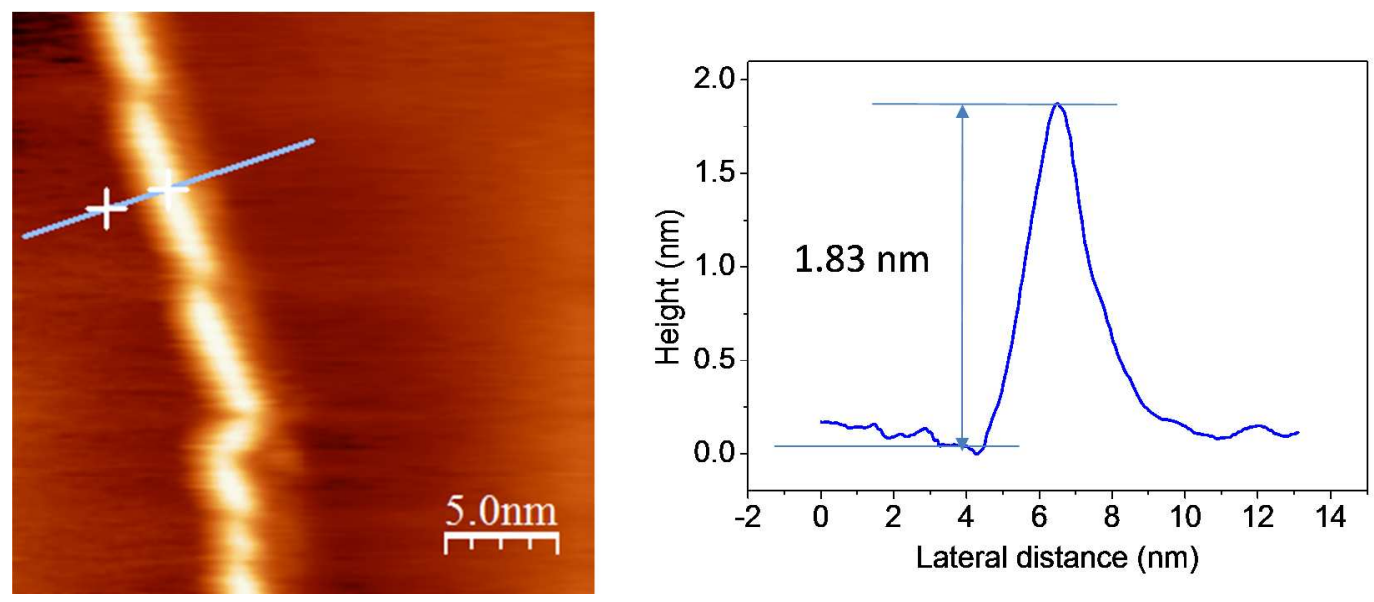

Figure S7: (a) STM topographic image of P5BT on HOPG. (b) measurement of height of the single polymer chain from STM image 


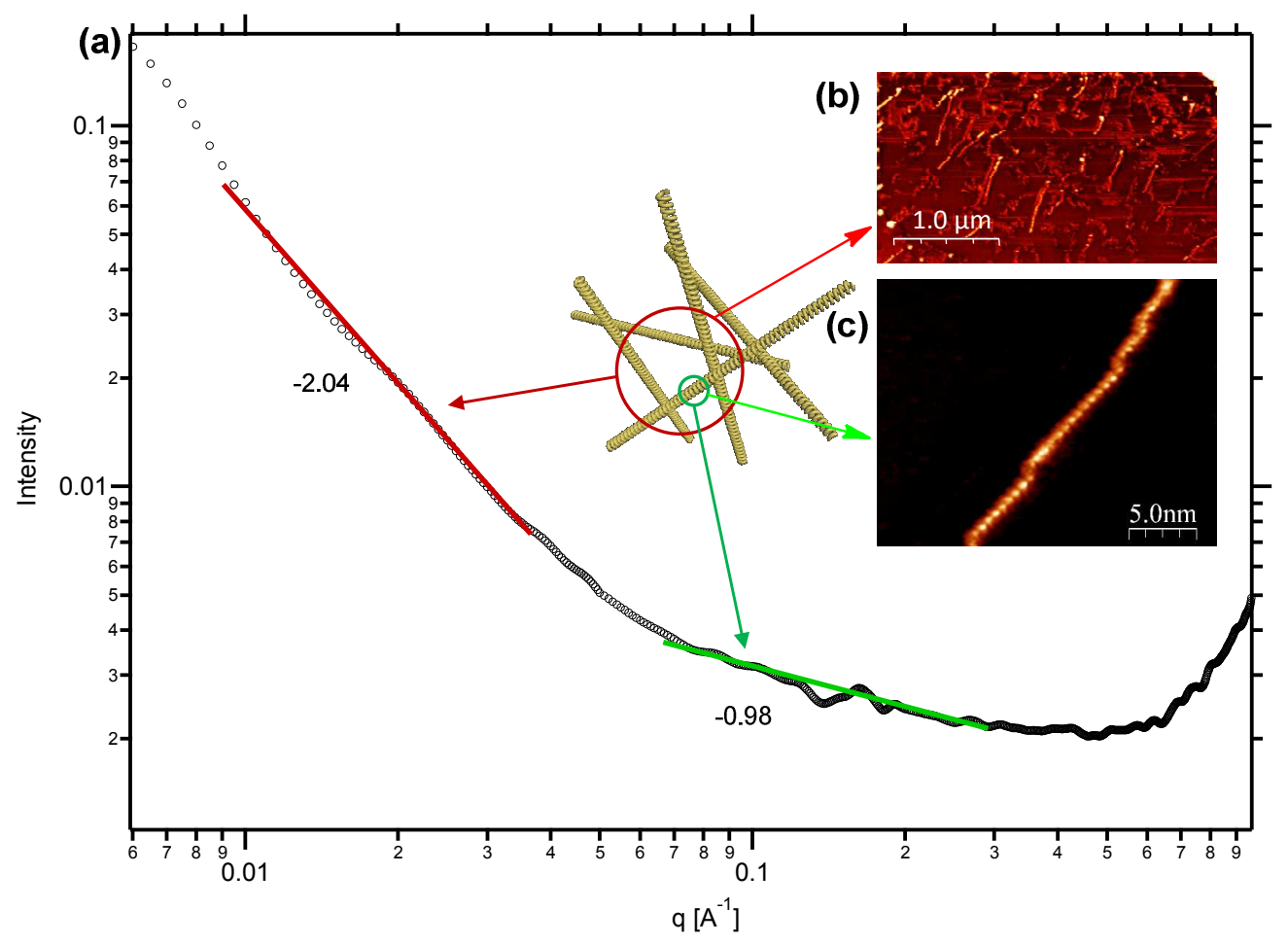

Figure S8: (a) SAXS spectrum of P5HT in THF (1mg/mL). (b) AFM image of P5BT on HOPG. (c) STM image of P5BT on HOPG.

Simulation study: A model of poly(ortho-thiophene) that included 16 ortho-thiophene monomers was used to computationally determine an optimized single chain structure (see Figure s7). The calculations were based on the semi-empirical quantum method, PM3 [For a review, see Stewart, J. J. P. (1998). "PM3", Encyclopedia of Computational Chemistry, Wiley], which uses a Hamiltonian that is parameterized to reproduce a large number of molecular properties. The PM3 geometry optimization was converged to a RMS gradient of $0.001 \mathrm{kcal} / \mathrm{A}-$ mol. The resulting structure was then fit to the parametric equation for a helix defined by the position of Sulfur atoms:

$$
\begin{gathered}
x=r \cos (\theta) \\
y=r \sin (\theta) \\
z=p \theta+A
\end{gathered}
$$

where, $\{\mathrm{x}, \mathrm{y}, \mathrm{z}\}$ is the position of Sulfur atoms in Cartesian coordinates, $r$ is the radius of the helix, $p$ is the pitch and $\theta$ is the angle subtended by a point at the helix's axis (radians). Helix parameters: Radius $(r)=3.62 \AA$; Pitch $(\mathrm{p})=0.9 \AA /$ rad (every $\sim 3$ thiophene monomers or a pitch length of $5.65 \AA$ ) , Offset $(A)=-17.0$ 

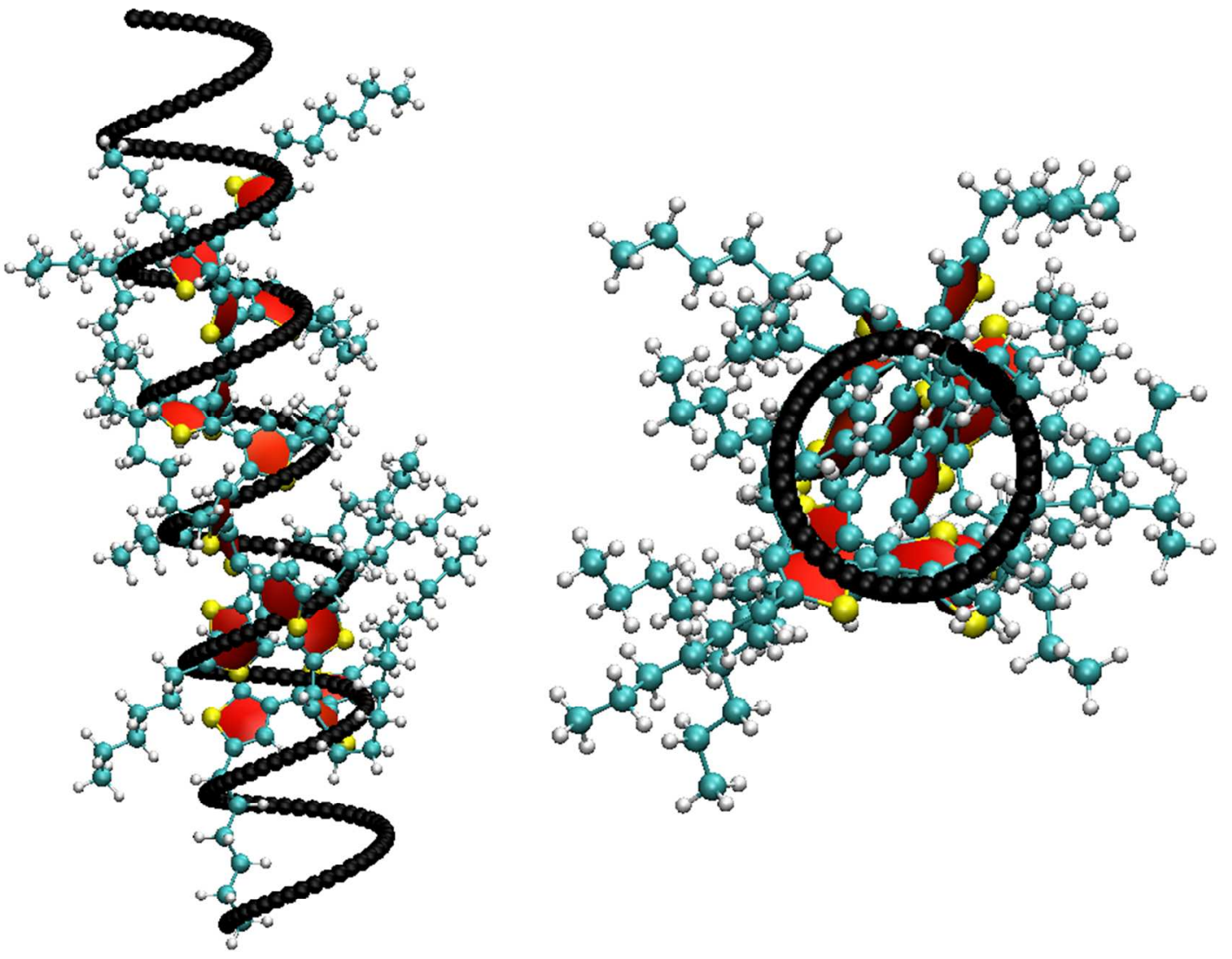

Figure S9: optimized single chain structure of poly(ortho-thiophene) with 16 units calculated based on the semi-empirical quantum method, PM3 


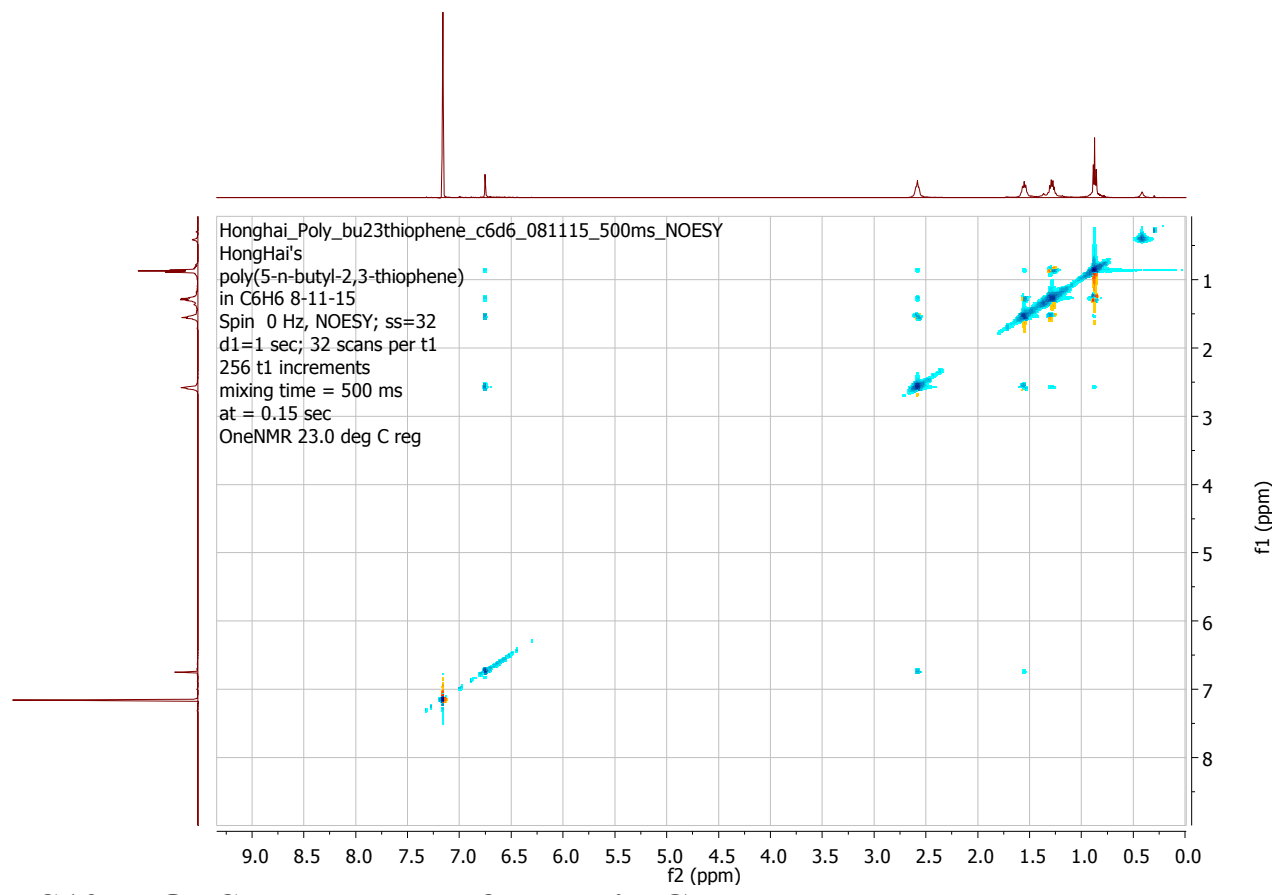

Figure S10: NOESY spectrum of P5BT in $\mathrm{C}_{6} \mathrm{D}_{6}$

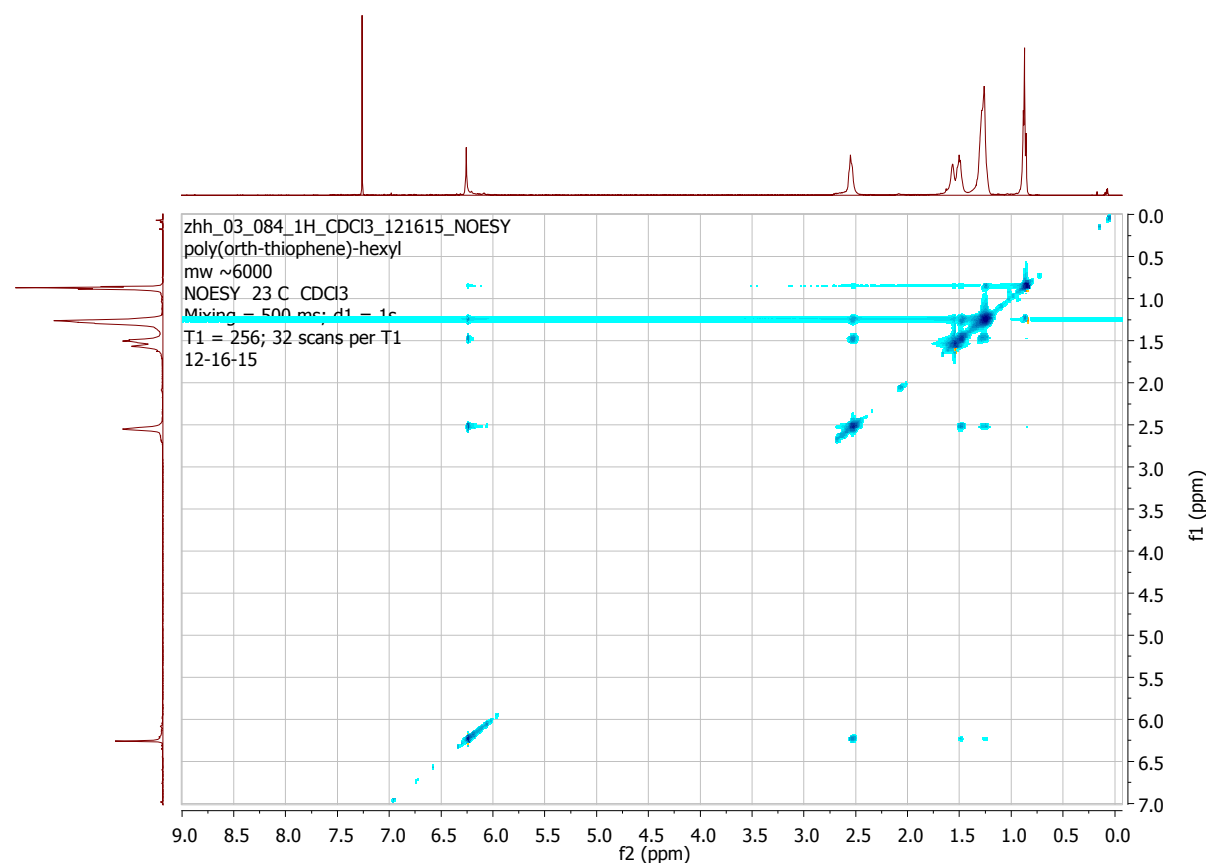

Figure S11: NOESY spectrum of P5HT in $\mathrm{CDCl}_{3}$ 


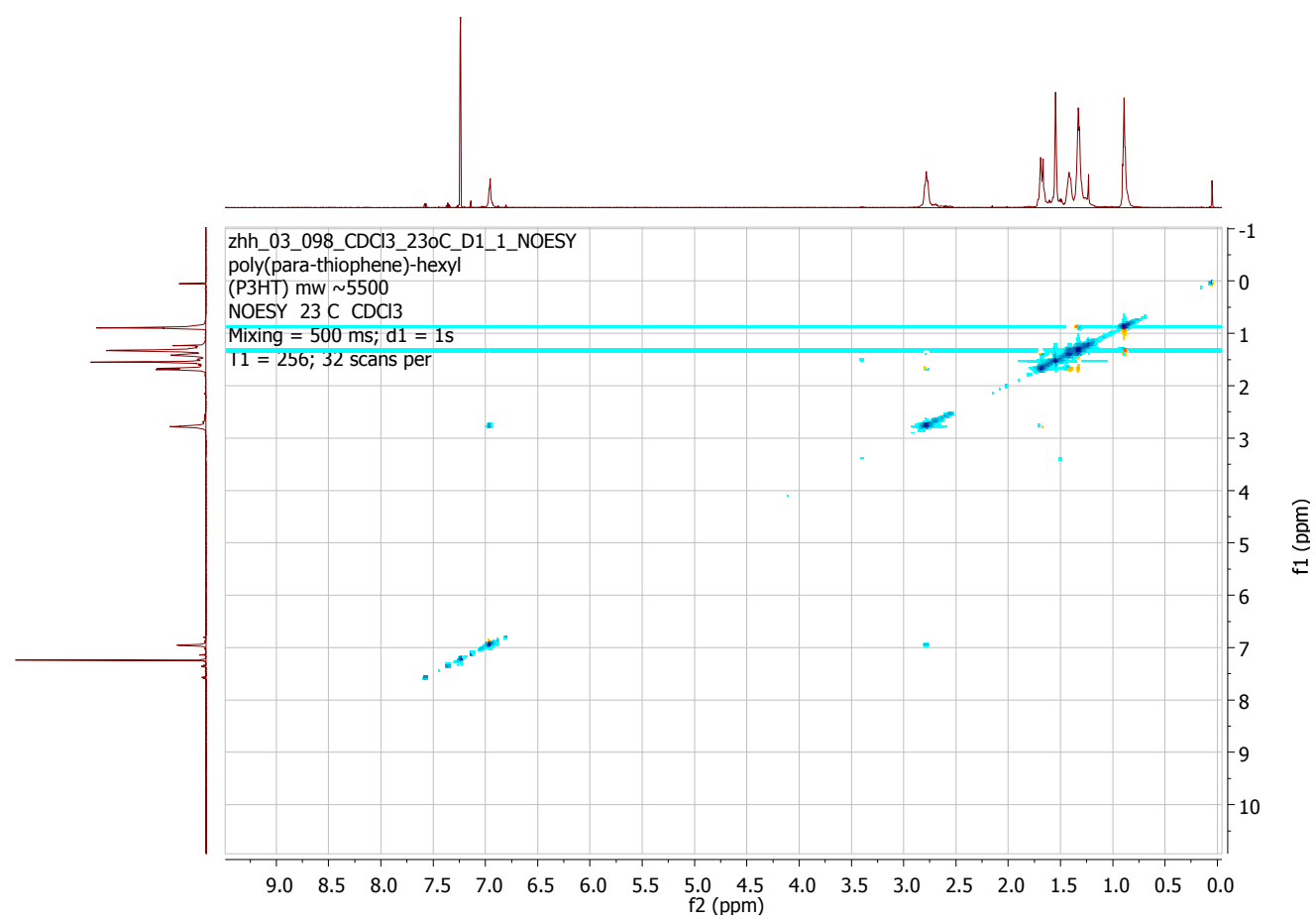

Figure S12: NOESY spectrum of P3HT in $\mathrm{CDCl}_{3}$

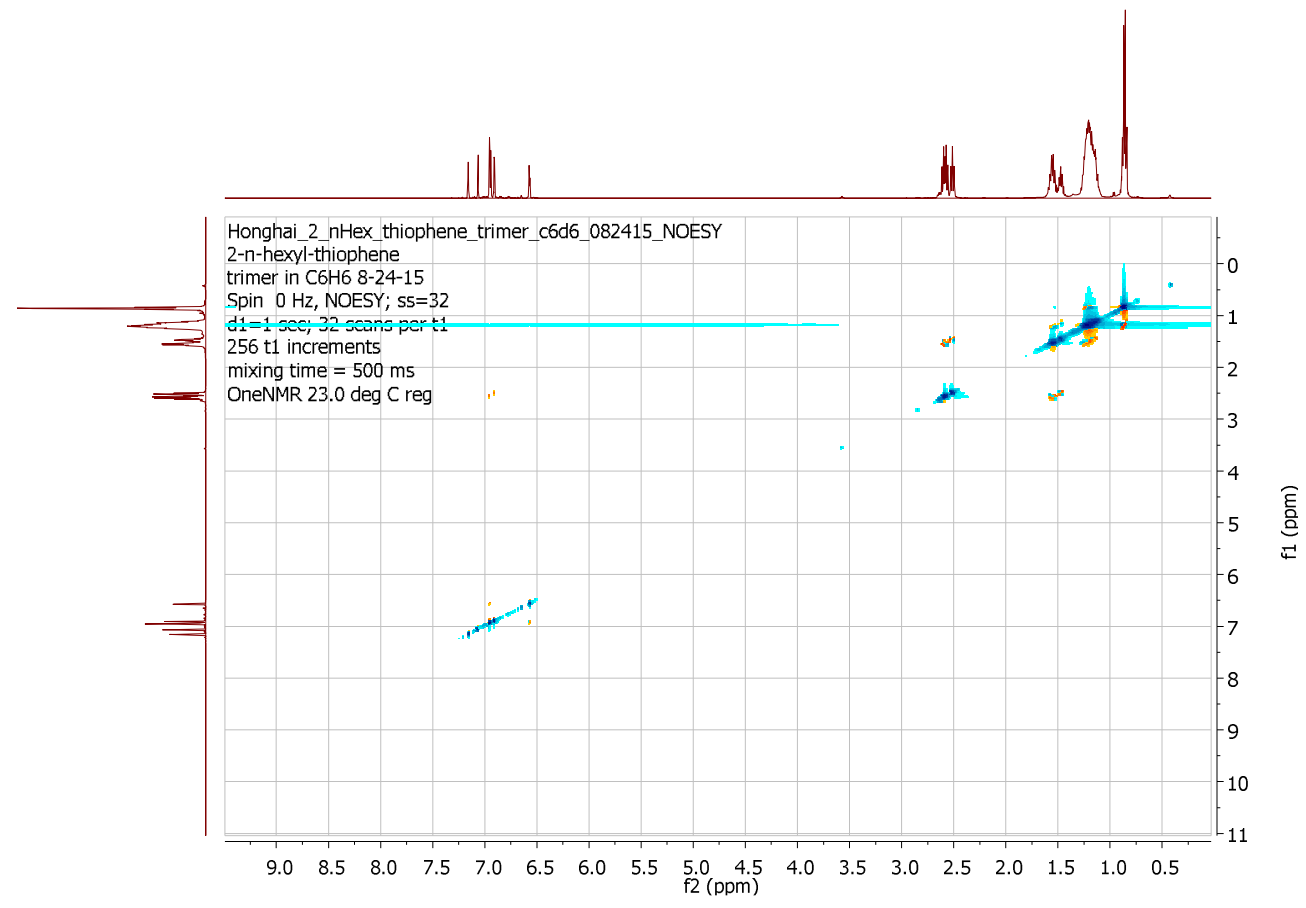

Figure S13: NOESY spectrum of trimer 7 in $C_{6} D_{6}$ 


\section{Reference:}

1. J. L. Brusso, O. D. Hirst, A. Dadvand, S. Ganesan, F. Cicoira, C. M. Robertson, R. T. Oakley, F. Rosei, D. F. Perepichka, Chem. Mater. 2008, 20, 2484-2494;

2. Zhang, H. H.; Xing, C. H.; Hu, Q. S.; Hong, K. Macromolecules 2015, 48, 967-978.

3. L. chen, S. R. Puniredd, Y. Z. Tan, M. Baumgarten, U. Zschieschang, V. Enkelmann, W. Pisula, X. Feng, H. Klauk, K. Mullen, J. Am. Chem. Soc. 2012, 134, 17869-17872. 
Proton and Carbon NMR Spectra:
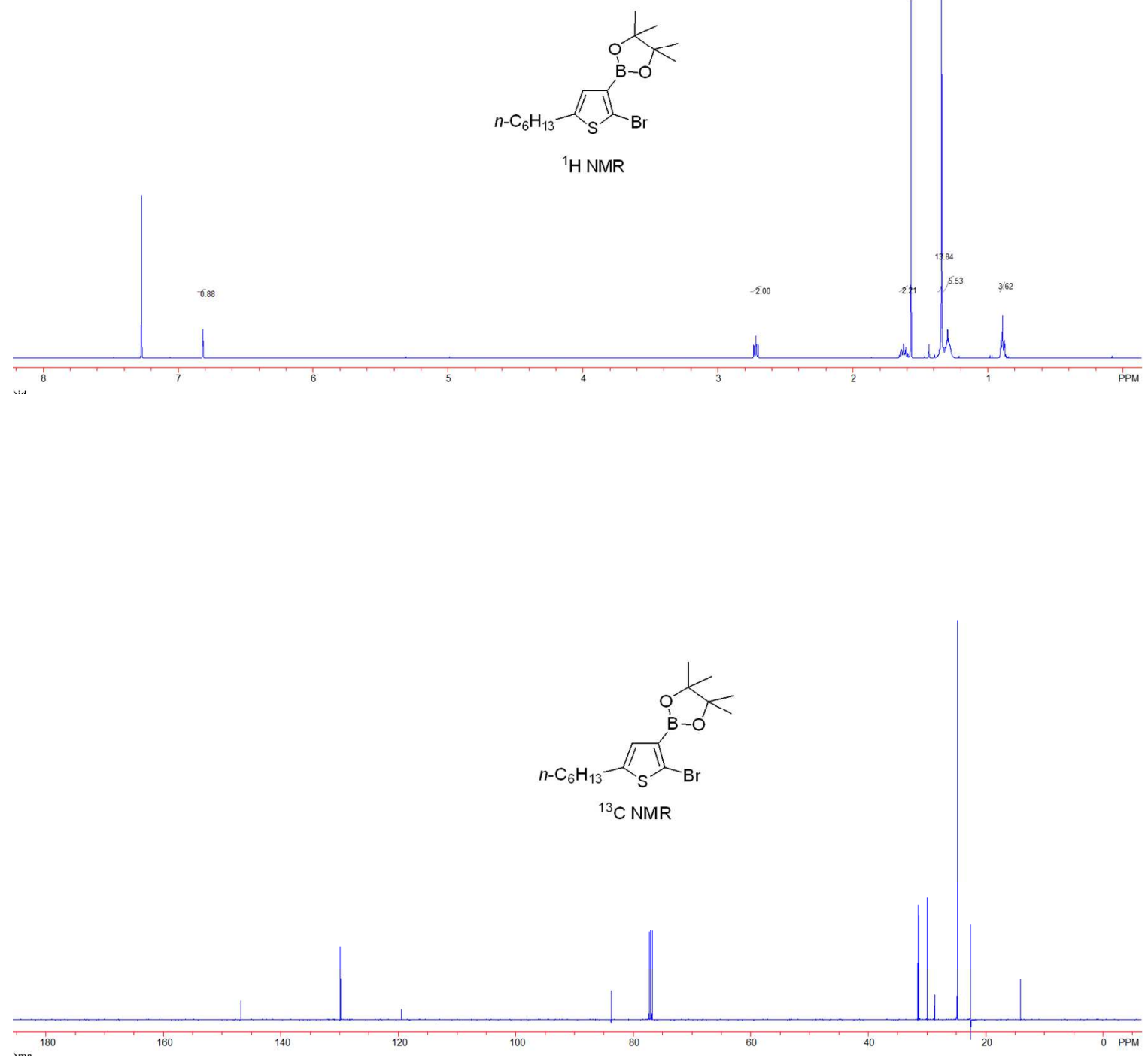

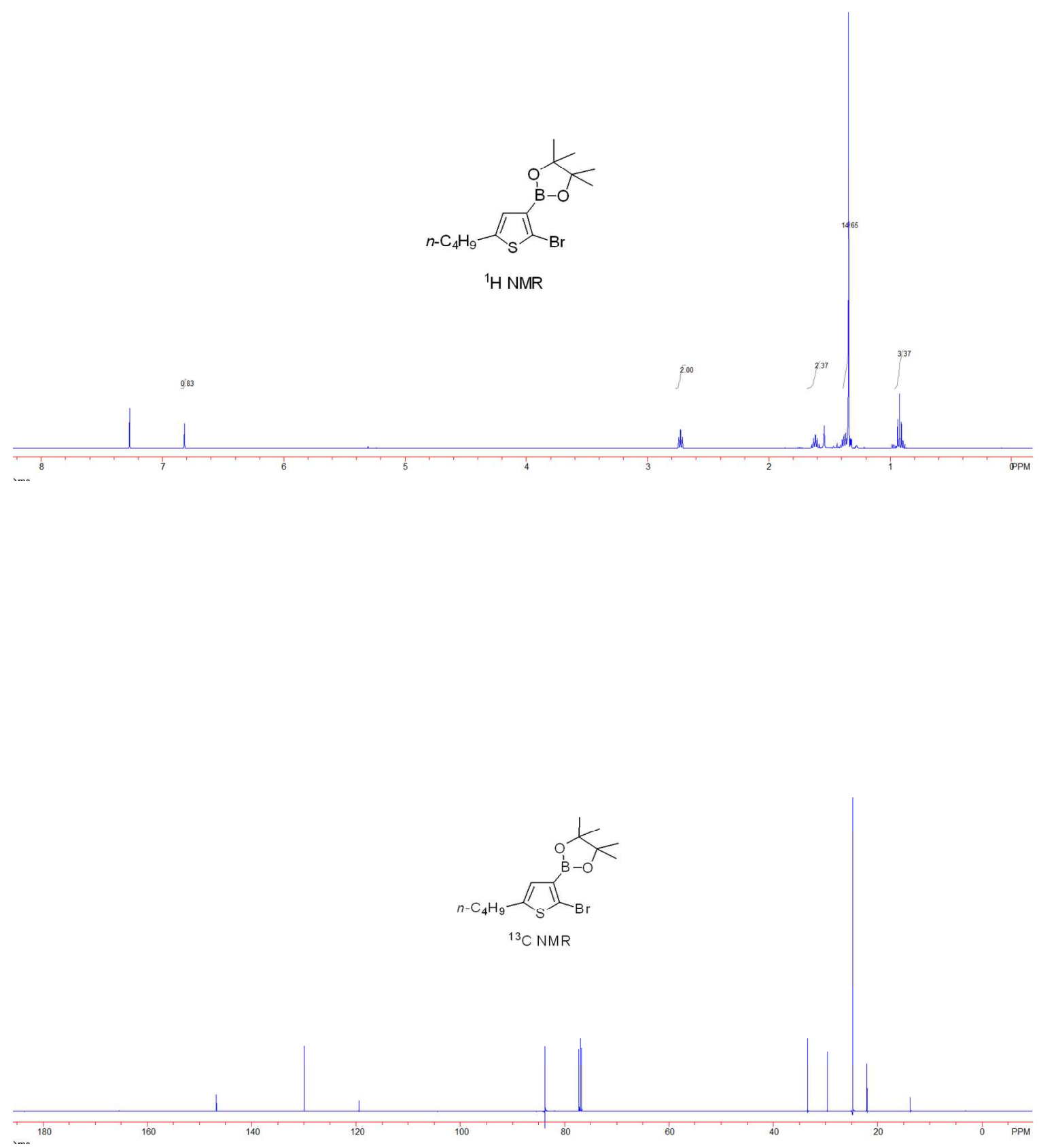

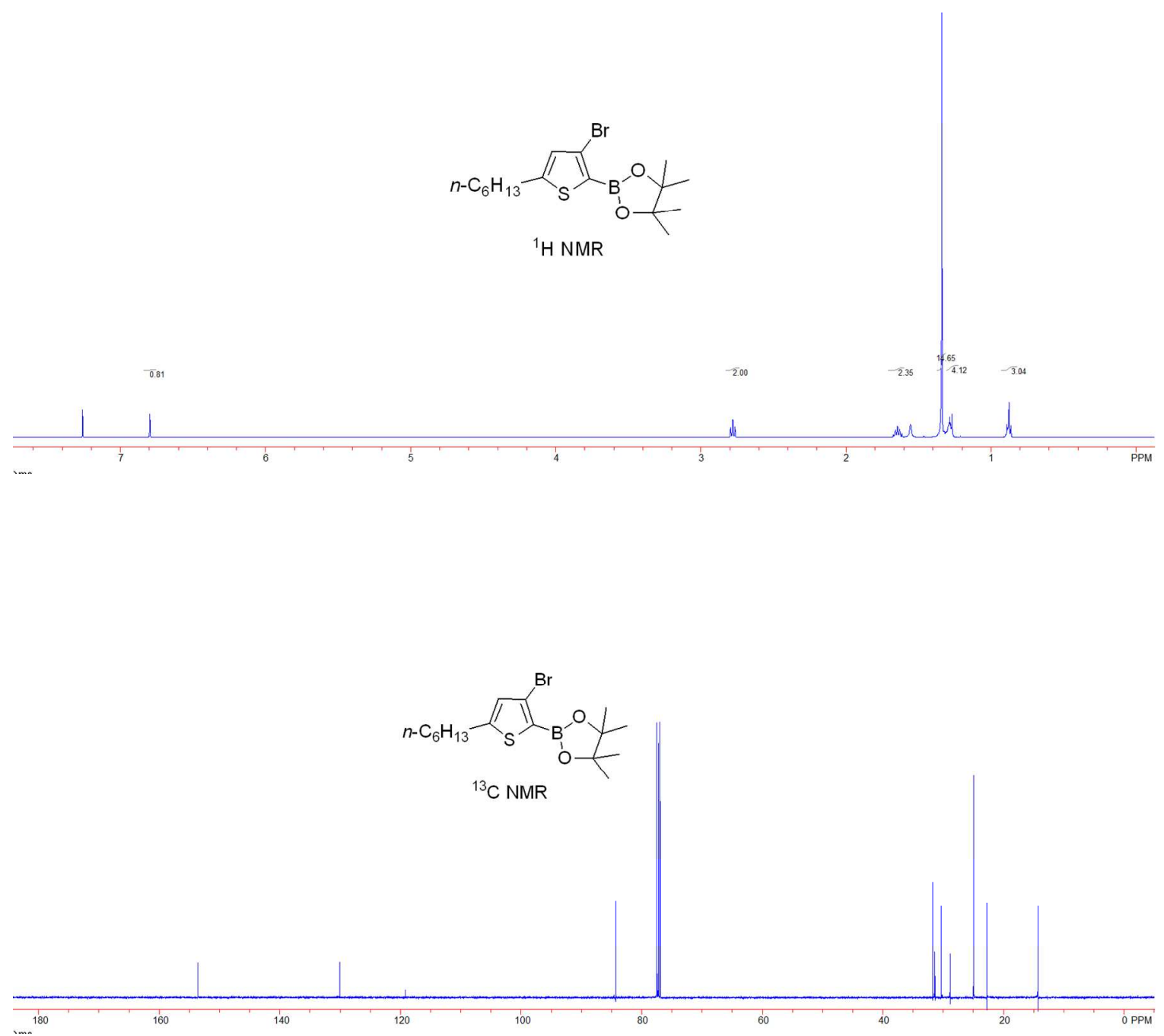

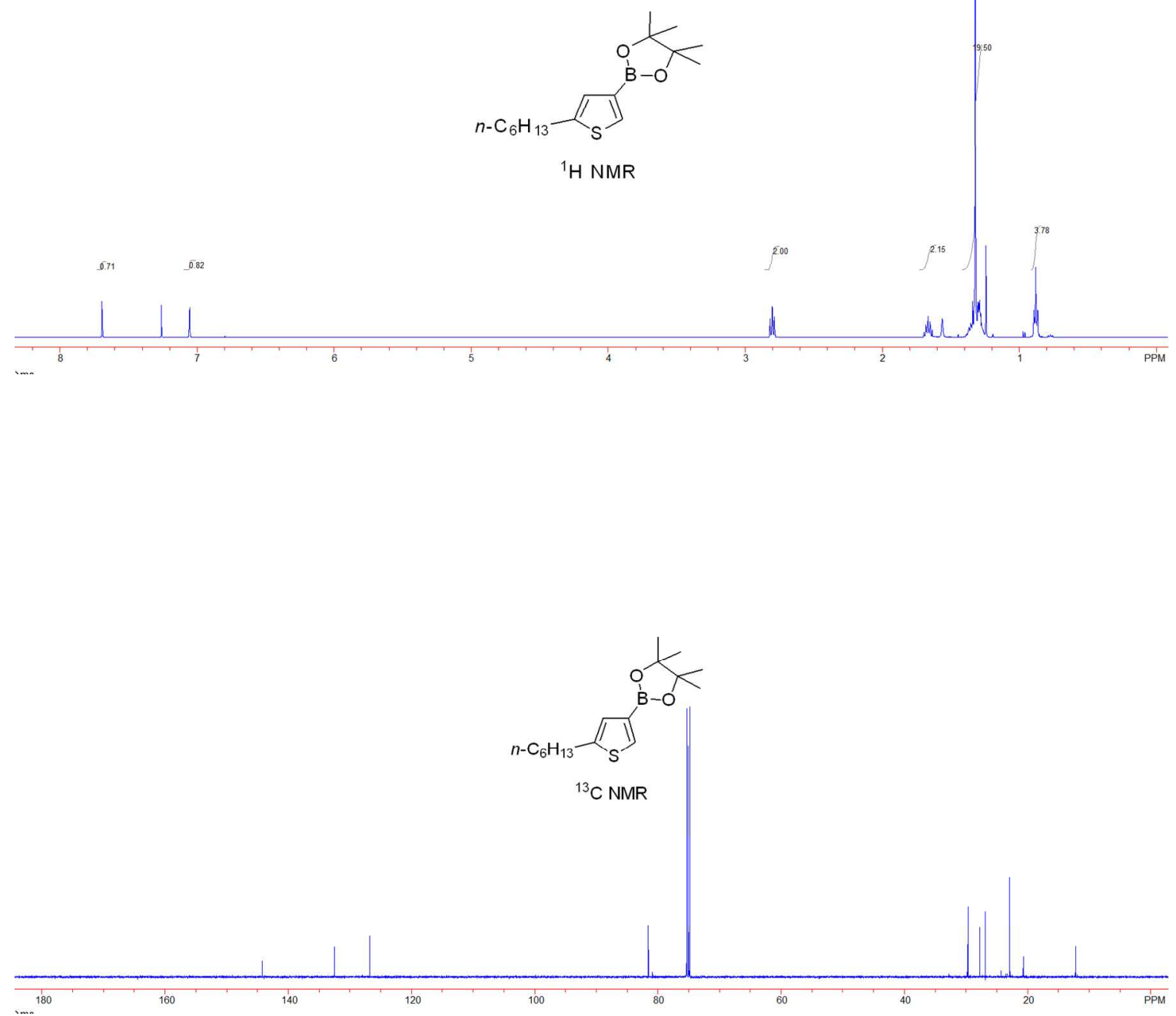

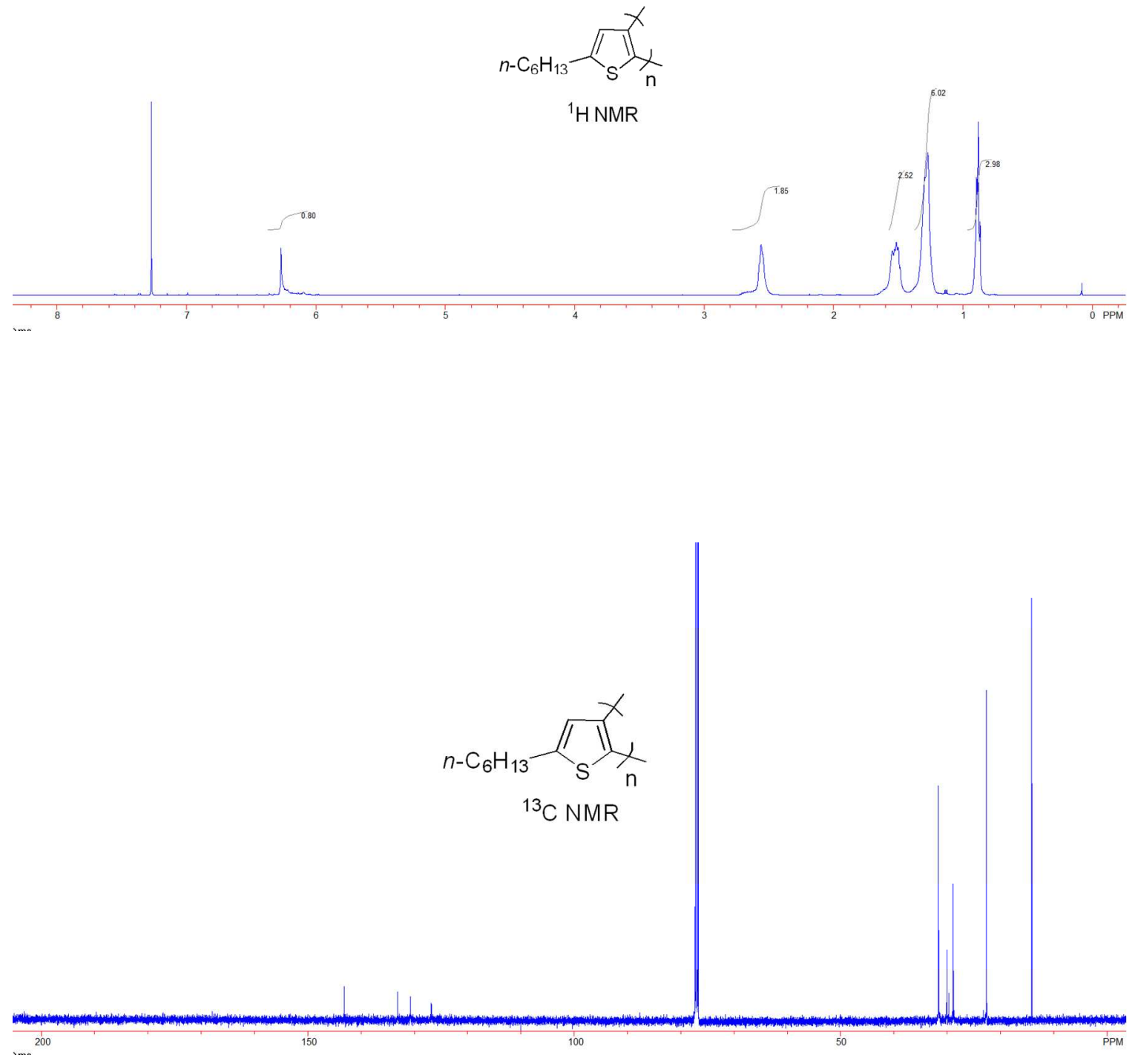

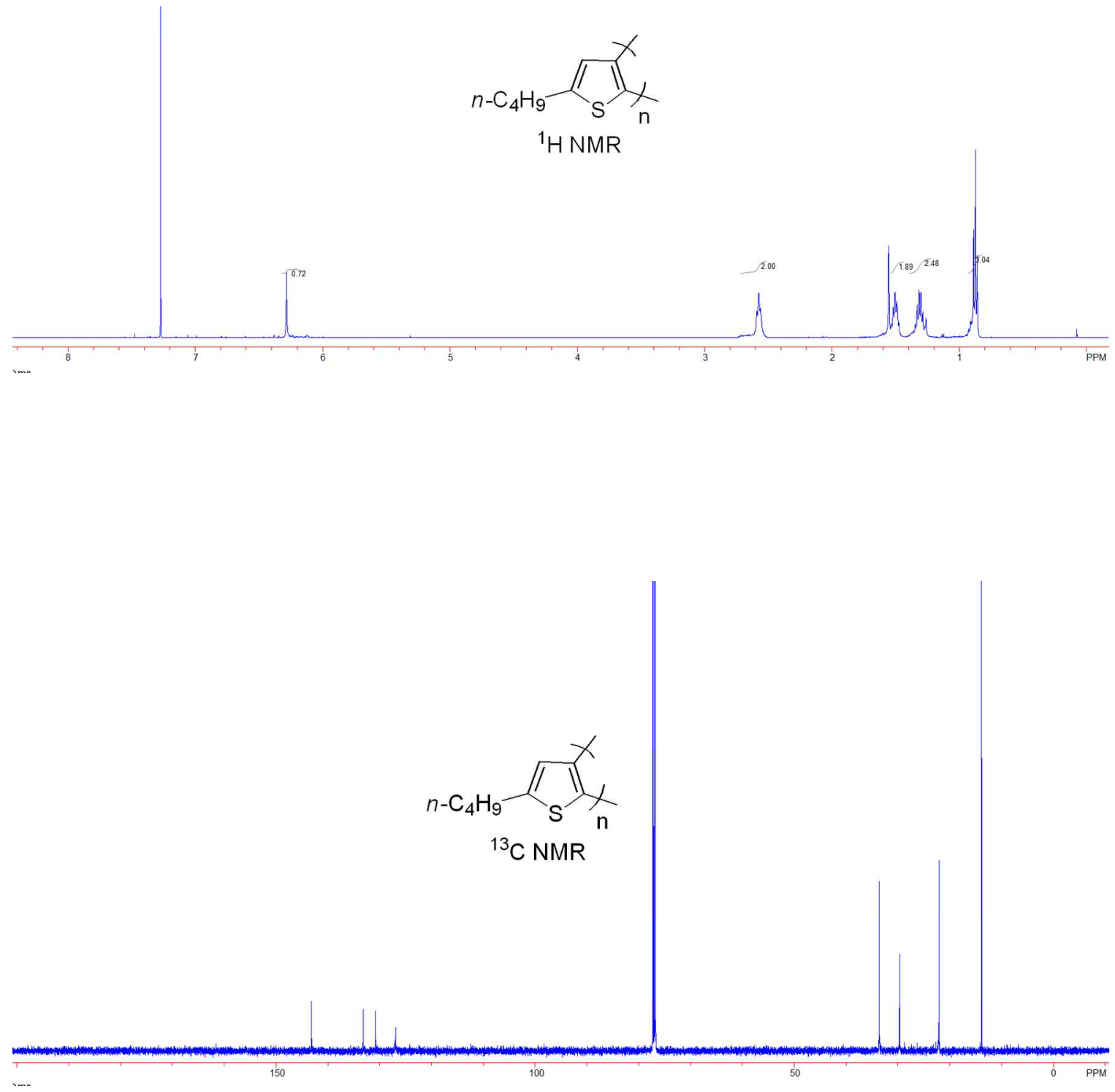